\title{
InEQUALity AND The Future of Global History: A Round TABle Discussion
}

To cite this article: “The Future of Global History: A Round Table Discussion.” Journal of Indian Ocean World Studies, 3 (2019), pp. 53-81.

More information about the Journal of Indian Ocean World Studies can be found at: jiows.mcgill.ca

(C) This is an Open Access article distributed under the terms of the Creative Commons License CC BY NC SA, which permits users to share, use, and remix the material provide they give proper attribution, the use is non-commercial, and any remixes/transformations of the work are shared under the same license as the original. 


\section{Inquality and the Future of Global History: A Round Table Discussion}

\section{Abstract}

The following is an edited transcript of a roundtable that took place at the University of Glasgow in September 2018. The roundtable was organized by Dr. Julia McClure in conjunction with the Poverty Research Network's conference - Beyond Development: The Local Visions of Global Poverty. That conference brought into focus the ways in which the global and local levels meet at the site of poverty and highlighted the different conceptions on the global are generated from the perspective of poverty. The roundtable brought together leading scholars from Europe, Africa, Asia and North and South America to take stock of global history as a field, to consider the role of existing centres of knowledge production, and to assess new directions for the field.

Panellists

Amitava Chowdhury - Associate Professor, Queens University, Canada

Sarah Easterby-Smith - Senior Lecturer, University of St Andrews, UK

Norberto Ferreras - Associate Professor, Universidade Federal Fluminense, Brazil

Omar Gueye - Professor, Cheikh Anta Diop Université, Senegal

Andrew MacKillop - Senior Lecturer, University of Glasgow, UK

Meha Priyadarshini - Lecturer, University of Edinburgh, UK

Steven Serels - Research Officer, Martin Luther Universität Hall-Wittenberg, Germany

Jelmer Vos - Lecturer, University of Glasgow, UK

Moderator

Julia McClure - Lecturer, University of Glasgow, UK 


\section{Introductory Remarks}

\section{Julia McClure:}

Since its emergence as a distinct field in the 1980s, global history has often focused upon macro-economic analysis and the emergence of interdependent global financial systems. Global historians have examined the flow of capital and commodities or the material culture of luxury and art as tangible traces of global connections. Poverty, often defined in relation to the lack of money, resources, and luxury goods, presents itself as a kind of historiographical antithesis to global history. Poverty has been in global history's blind spot. Poverty has been seen, if at all, as an unfortunate bi-product of global processes. Yet poverty is not only a consequence of global connections but has also been a productive force. Poverty is essential to the fabric of connectivity and poverty has been essential to the projects of world making.

The 2013 publication of Thomas Piketty's Capital in the Twenty First Century caused a seismic shift in the social sciences, putting inequality firmly back on academics' research agenda. ${ }^{1}$ For historians of race, gender, and capital, inequality has always been central, yet the recent 'inequality turn' opens up new directions for thinking about inequality that are still to be fully realised in the field of global history. Focusing on inequality gives us a new way to conceptualise connectivities, to think of the frictions, and to problematize some of the normative assumptions around the framework of connections. The focus on inequality is tied to the environmental turn, our understandings of the finite nature of resources, and the unequal effects of climate change that are intensifying inter-national and intra-national socio-economic inequalities around the world. Renewed emphasis on inequality also raises new possibilities for bringing poverty out of the shadows and placing it at the centre of new global histories.

This interest in the role of poverty and inequality in global history arrives out of my own research. The methodological questions around 'doing global history globally' and 'doing global history from the bottom up' have been central to my own work. My recently published book The Franciscan Invention of the New World (Palgrave Macmillan, 2016) is an intellectual and socio-political history of a radical religious movement known as the Franciscan Order. ${ }^{2}$ The Franciscan Order emerged as a rejection of monetarisation, marketization, and to the values engendered by these new economic systems in the late Middle Ages. Franciscan monks got into disputes with elites in Europe about the legitimacy of individual property, disputes which had a lasting impact on the concepts of property and rights. The Franciscan Order was also the first truly global movement to emerge from Europe. Franciscans reached East Asia before Marco Polo; they quickly establishing themselves in North Africa and the Middle East; and they were the first

1. T. Piketty, Capital in the Twenty First Century (Harvard: Harvard University Press, 2014).

2. J. McClure, The Franciscan Invention of the New World (Palgrave Macmillan, 2016). 
to transplant their religious order to the Americas. Their precocious global history was shaped not by the principles of acquisition that undergirded imperial expansion, but by a religious curiosity rooted in notions of poverty.

This earlier research has led directly to my current research project, The Poor Atlantic, which explores poverty and charity in the making of the Spanish empire. My research asks not only how empires made poverty but also how poverty made empires. In my research I examine poverty not only as an economic condition but also as a social relation and legal subject. Processes of impoverishment and the legal and institutional regulations of poverty have been mechanisms of governance that have contributed to the construction of the global order. I examine how theological, moral, and legal conceptions and management of the poor played a role in projects of nation- and empire-building to expose how poverty helped make the modern world.

I have convened this roundtable to launch the global history program at the University of Glasgow. Unlike similar programs elsewhere, this program will focus specifically on the global history of poverty and inequality. The city of Glasgow is a suitable site for this kind of research because its own history has been shaped by, amongst other things, the slave trade which brought forced migrations to Glasgow, the clearances and impoverishment that led to migration from Glasgow, and industries such as ship building that have made Glasgow an important node in global processes.

This roundtable is taking place in connection with the conference Beyond Development: The Local Visions of Global Poverty, an AHRC and GCRF funded project of the Poverty Research Network, which aims to engage the interdisciplinary perspectives across the arts and humanities and social sciences to deepen and diversify our understandings of poverty. I established the Poverty Research Project in 2016 to promote the interdisciplinary study of global poverty. The Poverty Research Network and its current AHRC project aims to re-orientate the field of global history to focus upon poverty and to consider the ways in which global history can deepen our understandings of poverty. Poverty is part of our global condition, and as global historians we need to understand how we arrived here, and what role poverty has played in the making of the modern world.

Today our panellists have been invited to share with us their own stories of how they became interested in global history, how they have related to themes of poverty and inequality, and whether they see the direction of global history changing in the future. 
Round One: The Field of Global History

In the first part of this round table the panellists were asked to introduce themselves, recount the path that led them to work on global history, and consider the ways the field has changed.

Amitava Chowdhury: While my research interests are quite diverse, empirically, my work is mostly rooted within the span of the British Empire between the eighteenth and twentieth centuries. In the main, I am interested in the histories of labour migrations and forms of forced labour. Having earlier trained and worked as an archaeologist, I was introduced to what was then called world history in 2004, when I started my graduate work at Washington State University. ${ }^{3}$ At that time, Washington State offered the only graduate programme in world history in the entire United States, and you could actually graduate with a major field in world history. However, the way scholars imagined world history in the early years of the first decade of this century differs significantly from what we have come to understand as global history in the last few years.

In 2004, we still very much traced the genealogy to the post-First World War era of Spengler and Toynbee, which was later on bolstered by the scholarly efforts of William McNeill. Some connected such origins with a deeper history that went back to Herodotus stating that nation-state centric histories were an anomaly in what has always essentially been a universalist effort. To be sure, the main goal of world history was to move away from the nation-state as the primary unit of analysis, but, nevertheless, world history of those years still presupposed a given spatial unit only to be filled up by the actions of the actors in that geographical area.

The scope of research was also circumscribed. While some took a different route, others thought of world history as a synthetic field not based on new empirical primary research. ${ }^{4}$ It was shortly afterwards that historians drew up strong positions separating world and global history, and by the end of the decade, global history as a separate field was firmly ensconced in American and European academia. ${ }^{5}$ Global history emerged not merely as a history of globalization, but rather as a history of integration. It was imagined and practiced not merely as a critique of units of analysis, but more as a radical critique of the overall organizational schema of post-Enlightenment thought. I therefore see different genealogies, different goals, and different methods that separate world and global history. While world histories, by and large, attempted larger generalizations,

3. Note that several US programs still prefer to call the field world history and have shunned the term of global history. 4. See, for example, Patrick Manning's statement: "It remains the case that world historians largely rely on secondary sources rather than on their own primary research." In Palgrave Advances in World Histories, ed. Marnie Hughes-Warrington (Basingstoke: Palgrave Macmillan, 2004), 49.

5. Of course, Bruce Mazlish has for quite a while identified the differences, but the form that global history took post2010, did not exactly align with Mazlish's version of global history. On Mazlish's claim, see for example, Bruce Mazlish, "Comparing global history to world history," The Journal of Interdisciplinary History, 28, 3 (1998). 
global history is empirically driven and tends to illuminate local histories of larger global processes.

I also want to comment on Julia's proposal of organizing global history around the question of inequality. My own research is not directly in the field of inequality, but our own Global History Initiative here at Queen's serves as an umbrella for a few research clusters, and, given our newly established partnership with the Glasgow Poverty Research Network that Julia directs, I can well imagine a forthcoming collaborative venture in this area. But let me quickly note a few things related to global history and inequality. Several broad avenues come to mind: one could examine local histories of poverty brought about by global processes of structural inequality; or, alternatively, one could look at horizontal and synchronic historical analyses to uncover the histories of structural inequality as consequences of colonialism or other processes. Or, we could study ecological and environmental determinants that reveal how inequality adversely affects some parts of the world more than others. I am sure there are other fruitful avenues that others may comment on. Instead, I would like to briefly talk about methodological and historiographical inequality - a project that would help us imagine a more usable global history for global purposes. My point is about structures of knowledge and the categories of analyses that we work with. Postcolonialists have shown us how local categories of thought born within specific historical contexts in Europe assumed universal pretensions through the vehicle of colonialism and empire. ${ }^{6}$ Many locally-produced ideas on freedom, class, gender, democracy, and sovereignty were results of European historical processes. They were not human universals and they can do very little to adequately capture the complexities of societies in many parts of the world (ironically, within Europe as well). So, one way to address inequality is to free history from the methodological and historiographical inequality that was injected into post-Enlightenment thought, which eventually travelled the world and determined the shape of nineteenth- and twentiethcentury historiography. One could thus make a connection between the intellectual inequality that is so pervasive in our inherited historiography, structures of colonialism, and global poverty and inequality. To me, this is a rather urgent task.

Norberto Ferreras: I am a professor at the Universidade Federal Fluminense in Brazil. I am researching the International Labour Organisation (ILO), and forced labour through the ILO and Brazilian history.

The question with which Julia presents us asks if there will be global histories of inequality in future global histories, and I think this is a very good question to reflect on with regard to global history. I will talk about this from the perspective of the Global South and the perspective of a peripheral country. This round table seems timely since now global history has become the new fashion in Brazil. For example, in my university today,

6. One could cite a whole host of works on this, but Ranajot Guha's History at the Limit of World-History (New York: Columbia University Press, 2002) is a good place to begin. 
four out of the sixteen courses we are offering this semester are global history courses. This is very unusual, because in other countries, for example Argentina or Mexico, there are no global history courses at all. Brazilian historiography is very 'fashionista': it likes to follow the fashionable trends. In Brazil, we like to take these fashions and explore the possibilities they give us.

I want to explain why it is that global history has become so popular in Brazil. For us, our history - Latin America history - is related to our history of colonisation, and this is naturally part of ongoing global processes. Colonisation has been a neverending process, one that was not brought to an end with independence. It is not just an institutional process, we need to think in political, cultural and economic ways to understand how European or the United States colonize Latin Americans societies. ${ }^{7}$ At this moment we are experiencing another turning point in the civilization process and a wave of new colonialism. This new wave has brought rightist governments to power across Latin America, with the exception of Mexico.

It is important to emphasise that I am speaking from a Brazilian point of view. In Brazil, in 1928, Oswald de Andrade presented his anthropophagic manifesto in which he discussed the intellectual relationship between Brazil and the most important intellectual and artistic movements in Europe. He established some statements, like to move from the Shakespearian "To be or not to be, that is the question" to "Tupi or not Tupi, that's the question". Such statements pointed to the necessity of rescuing the indigenous roots of Latin-American history, and its intellectual and social formation. ${ }^{8}$ The Tupi language is one the most diffused language families in Pre-European America. We need to understand that Brazil must be anthropophagic, must swallow all European culture and we must swallow and digest the coloniser. It means that Brazilian culture does not simply accept western culture; Brazilains process it, reflect on it, and then they use in they own way. This is the only way to understand what is going on with us and to the others.

Consequently, we, as Latin-American historians, need to appropriate global history in a creative way. We cannot remake the entire global history, from the theory or methodological point of view, but we must be part of this History movement and to collaborate with our point of view. We need to understand our own globality. America was built globally, and - in the turmoil of ideas and people movement from the very beginning - incorporated into commercial networks, but in a fragmented way. The globality proposed by our disciplines is fragmented too. We need answers about how we built our relationship with other regions of the world, mainly Europe, Africa, and North America. We think ourselves as a separation in constant transformation. Globality allows us to move from methodologic nationalism approaches, to release ourselves as a part of

7. See, for example: Michael Hardt and Antonio Negri, Empire (Cambridge, Massachusetts, Harvard University Press, 2000).

8. Oswald de Andrade, "Manifesto of Pau-Brasil Poetry," trans. Stella M. de S. Rego. In: "Latin American Literary Review XIV: 27" (January-June, 1986): 184-87. 
it, and not be isolated.

When Julia asked us about inequality I remembered, of course, Thomas Piketty's work, "Capital in the $21{ }^{\text {st }}$ Century", which is especially interesting because of its approach. Despite the indisputable importance of the work, one of the limits it presents is that the empirical research depends substantially on data collated by nationalist states. In general, only the states have the resources and are equipped with a large and efficient bureaucratic apparatus are capable of collecting and organising systematically micro-statistical data on income and wealth. In that way, global inequality itself creates the conditions for analysing global inequality, and what should be explained shapes the explanation in sociological terms. Global inequality is a structure of our epistemology currently based on it. In empirical terms, writing a history in equal parts, as Romain Bertrand show us in "L'Histoire à parts égales", presupposes a simple archival symmetry that doesn't exist at all. ${ }^{10}$ That is one of the challenges of social science today: social scientists must be able to navigate different empirical repertoires and give to the analysis a status of scientific validity. If not, we are creating practices of post-colonial domination. Such as the contemporary political economy is a system that radiates at a different historical space time of the world to common metric standards. This analysis will be centred for us in Brazil at this moment.

Omar Gueye: I am a professor of history at Cheikh Anta Diop University, Dakar. My main research deals now with the 1960's in Africa. I have already written a book on "May 1968 in Senegal", which deals also with the French-speaking countries, after many other works on labour history, particularly the history of the Labour code in French-speaking countries. I am also a graduate in cultural heritage. For today my talk is about global history and its relationship to Africa. My interest in the subject has been growing since my stay in Harvard as a fellow at the Weatherhead Initiative on global history where I contributed the chapter on Africa for the Global History, Globally volume (published in 2018).

Andrew MacKillop: I am a senior lecturer in Scottish history at the University of Glasgow. I too am playing a role in developing global history here at Glasgow. I arrived from the University of Aberdeen almost exactly a year ago, I think about the same time or three or four months before Jelmer. In some ways I am masquerading here. I am in no way, or at best only in some ways, a historian of global history. What I do is look at the global boundaries of early modern Scotland as a way of testing some of the wider frameworks of early modern globalisation. I am really an historian of human mobility and I think it's interesting that we've already heard an emphasis on the well-

9. Thomas Piketty, Capital in the Twenty-First Century (Cambridge: Harvard University Press, 2013).

10. Romain Bertrand, L'Histoire à parts égales. Récits d'une rencontre, Orient-Occident (XVIe-XVIIe siècle) (Paris : Seuil, 2011). 
known move away from national frameworks towards the issues of labour. A peoplefocussed emphasis, I'm already beginning to notice, is emerging as a key issue in our discussions already. Over the last three or four years I have been doing comparative work on what I describe as the poor regions of Europe. These are the areas that the conventional models explaining proto-globalisation would deem as materially poor and suffering from structural inequalities. In that context, my work is really about exploring how those regions of Europe access Europe's global expansion.

Meha Priyadarshini: I teach at the University of Edinburgh and in our gathering today I feel I can safely say that I do global history. In fact, I am not sure I have ever before defined myself in this way publicly, partly because there remains a bit of scepticism regarding the field and one never knows how the label might be received. On the other hand, it's also true that if I say that I do "global history", it doesn't tell you much about my expertise, so to be more precise, I will also say that I work on connections between Asia and colonial Latin America. I hope that in describing myself in this way you can see why it is useful for me to be able to say that I do global history because I am not primarily a historian of Asia or of colonial Latin America, although I do know a bit of history of the two regions, but what I know a lot about (that experts on those two regions might not know as much about) is how the connections between Asia and colonial Latin America were forged and what impact they had. So, the label of "global history" helps me to break out of the categories of the traditional area studies, and also to define myself as someone who is interested in thinking critically about the global connections of the early modern period.

In terms of my educational background, like Amitava, I also did my $\mathrm{PhD}$ from a global history programme. I was very lucky that I arrived at Columbia University when the programme was starting because I'm not sure there were many universities at the time that would have allowed me to pursue the project that I ended up doing. On a very practical level, then, global history when institutionalized in a department can be very liberating in terms of allowing students the freedom to do projects that wouldn't fit a particular area studies model. And we are starting to see the fruits of history departments who have instituted a world or global history track. It wasn't always clear: I think people wondered whether I was going to be employable, and, I don't know if you had the same experience, Amitava, but I am proof that one can be employable even without a training in just one particular region of the world.

Sarah Easterby-Smith: I am a senior lecturer in history at St Andrews. I am a historian of science and I work primarily on the eighteenth century. I would normally think about inequality in terms of inequalities of knowledge and power rather than specifically money, although economics obviously plays a big part in all forms of history.

I first encountered global history as a PhD student at the University of Warwick. I started out as a comparativist working on French and British history. But the history 
department at Warwick "went global" while I was doing my PhD! From about 2006 onwards, one of my supervisors, Maxine Berg, and her colleagues devoted a tremendous amount of energy to organising reading groups and workshops to examine the possibilities that global history might offer, and how this label might set a new agenda for history as a discipline. These conversations were very formative for me as a doctoral student.

I then subsequently came across different interpretations of global history at the other institutions where I studied and worked - especially the European University Institute and the University of St Andrews. Indeed, at St Andrews we don't actually have a centre for global history; instead we have an Institute for Transnational and Spatial History. When I arrived in 2012, I initially felt a bit confused by the emphasis on the "transnational" instead of the "global". However, the longer I've been there the more evident it seems that the differences between these approaches are often, in fact, very small. I agree with Amitava that the labels "world" and "global" often refer to different methodological approaches. But the methodologies we use as "global" (or "world" or "transnational") historians are still under debate and thus in flux. As a result, it is often the case that the clearest distinction between "global", "world" and "transnational" is the semantic one; they do not necessarily describe radically different sets of questions, perspectives or scales (the one exception is periodisation, because "transnational" technically refers to the late modern era).

I'd like to suggest two possible topics for our initial discussion - one general point regarding periodisation and one more specific, about the ways in which historians of science have responded to global history.

With regard to the first, I think it's important to reflect on the ways in which global history is different when we are discussing an age before the advent of steam and telegraphs and fast communications. We can of course still have a holistic conversation with historians working on late-modern global history, but I do think that the significance of those practical constraints and structural differences always needs to be stressed.

With regards to the second, many historians of science have engaged actively with global history. Much of this work has retained the notion of 'inequality' as a central feature of the analysis. This can largely be linked to an aim to situate colonial and imperial histories in a broader framework, moving the discussion away from the now-hackneyed colonised-coloniser dichotomy and into histories of interactions, exchanges, secrecies and resistances. We can expand on that later if we want to.

Jelmer Vos: I came to global history as a historian of Africa studying the Atlantic slave trade as well as the history of Angola, with a special interest in commodities like rubber and coffee. By following the coffee commodity chain, I am connecting people in Angola to other places in the world, including the Netherlands and the United States.

Steven Serels: I have a joint position as a Visiting Scholar at Harvard University and as 
a Research Officer at Martin Luther Universität Halle-Wittenberg. My research focuses on the history of the Red Sea, but I would call myself a global historian. I have no problem staking that claim. Unlike many of my colleagues, I didn't come to global history after having been through an undergraduate education steeped in more conventional approaches. My unusual path to a $\mathrm{PhD}$ in history began with a Bachelors of Fine Arts. I began studying history as a graduate student at McGill University and immediately gravitated to the Indian Ocean World Centre. Indian Ocean Studies is structured around a very particular narrative of globalization. This field has been organized around the central claims: 1 ) that from at least the $11^{\text {th }}$ century, but maybe even earlier, a regional economy emerged that linked places as distant as China and East Africa through maritime connections that were cosmopolitan, successful, and produced wealth and abundance; 2) that this was until relatively recently the centre of the world economy; and 3) that Europe was a peripheral territory in this economy. Over the course of what we came to call modernity, the Indian Ocean World economy was either dismantled or fell apart as the rest of the world became integrated into a new global economy centred on Europe and the North Atlantic.

Indian Ocean Studies' stress on global interconnections seemed initiatively true to me. Perhaps this was a result of being the child of immigrants from a historically peripatetic community. Nonetheless, I continue to use this framework simply because I find it to be empirically true. Transregional interconnections across the Red Sea have historically been very important, so much so that the African Red Sea littoral should be considered as the real hinterland for Mecca. Global interconnections in the Red Sea are and have been life-sustaining. For centuries, communities in this region ate Indian grain. Without large, regular imports of food stuffs, Red Sea communities would not have been able to support themselves. I do not know what could be more global than that.

\section{Round Two: Inequality as the Future of Global History}

Julia McClure: When I used social media to advertise the round table it received a great response, with one responder describing the focus on inequality as "the much-needed paradigmatic change in global history". When I proposed this round table on "Inequality: the Future of Global History?" I expected more resistance to the proposition from global historians. In many ways, inequality has long been a dominant paradigm in global history. The 2000 publication of Ken Pomeranz's The Great Divergence focused upon international inequality through examining how wealth accumulated in the West. Yet The Great Divergence model was so prominent that it also overshadowed parallel or alternate inequalities both within nations and not visible through the lens of the nation state. This focus on the macro-analysis of inter-national inequality has also not made poverty its main focus. The questions I had for our panellists concerned how the future of global history will change, what will be the new directions in the global history of inequality, 
and what also does it mean when we think about poverty also as a framework for thinking about the world and about global history? Does that re-orientate our perspectives?

Omar Gueye: I focus mainly on African history and global history and, as Norberto said for Latin America, the history of decolonisation has not ended. African history, if I take the example of my country, Senegal, was probably a history in the French language in Senegal and, therefore, a legacy [of colonialism]. For Africans, there was an attitude of militancy in writing history and talking about history. The history programs taught to children during French colonization were "Our ancestors the Gauls". Young children in Africa, mainly from Senegal, were thus raised on the basis of the French system and had become good francophones, as I am today. So, it was as if after independence which meant political independence and economic independence - Africans also needed cultural independence, and it was especially a big challenge for history researchers who had to deal with many problems in Africa.

In our approach, we must then discuss some very interesting points about African history and global history. What is Africa's place in the global movement? And what is Africa? We should define - or redefine - Africa. Indeed, when we talk about Africa, we think mostly of a black Africa, so to Sub-Saharan Africa. So, the Maghreb, North Africa, is not concerned. Southern Africa is not concerned either. Moreover, only a "white Africa", in development, is in a way linked to globalization. We must then clearly redefine and clarify what Africa is. The question of methodology is raised. [In the colonial mind,] it was as if oral history was not history. [Oral narration, though,] is the main source of the book entitled, Sundiata: an Epic of Old Mali, written by Djibril Tamsir Niane. ${ }^{11}$ Even better, after Yves Person wrote his book, Samori - one of Africa's most important heroes - it was as if it was accepted that oral history can be considered a valuable source, and that African history has legitimacy and can be taught as such. ${ }^{12}$ Studying African history is an important contribution to the debate about peripheral history and global history. Until now, Africa has often been considered as part of "French history" or "British history". This debate could help to redefine Africa, as well as to challenge certain paradigms. In a nutshell, global history is a way to rethink Africa in relation to the global process. This framework is undoubtedly an opportunity to connect the human sciences with programs that can be widely shared around the world between African academics and their colleagues from other parts of the world. For global history, re-problematizing historical research paradigms in Africa is a new challenge.

Some questions I must answer relate to the growing interconnectedness that shapes modern life, as in the case of global history, by unpackaging - or repackaging - the unequal power relationships that shape international trade, geopolitics, and academic 
architecture. Is this new framework a chance to create or erase the profile of Africa? Another crucial question is who will fund the research. Many very important African studies centers are emerging all over the world, certainly, but what kind of research is intended to do? Search on what? That's the question. It is as if, for example, the definition of research topics depends on the interests of those who finance. For example, in medicine, research on the Ebola virus or HIV was conducted mainly because of its interest in the North, while the real challenge in Africa was and remains malaria. This medical example illustrates one of the reasons why I ask the question of how research should be oriented and why we should rethink colonial history in order to rehabilitate a true African history. Linking African history to Global history, on the one hand, and linking southern and northern institutions, on the other, are undoubtedly major challenges for our research network. Fortunately, we have collaborative working groups, like the one we have today in Glasgow, whose panelists come from many parts of the world. Finally, we need to define new research trajectories and especially strategies to achieve what we want to do, especially with African research and global history.

Andrew MacKillop: I suppose, in a sense, I'll stick unimaginatively to the issue of how I come to the subject of Global History, what are the recent trends in my work, and what possible directions and perspectives might flow from that work. As I said during the introductions, I came to global history from what would seem a very conventional set of starting points. I began my early work looking at the question of how early modern, mostly seventeenth- to early nineteenth-century Scotland - which is a small, very wet, impoverished Northern European society - shifted from its traditional intra-European culture of human mobility into a global framework. Scotland did so very rapidly, and everybody noticed it at the time. In under one-hundred years it goes from being known as a nation of emigrants inside Europe to being a nation of immigrants that are scattered across Arctic North America, in China, in India, the Caribbean and the areas of colonization in North America. Its history is not that of a polity globalising but of a people globalising.

Such a starting point is fairly conventional and arguably even potentially regressive. It makes me Eurocentric, to be sure. It privileges nation, if not in the modern sense, then at a certain territorial level. It certainly presumes a Scottish spatiality as the privileged unit of analysis. It's even a small unit of analysis, especially set against the wide parameters of global history. This perspective of course ties into diaspora, which has always been a theme of global history. That initial interest morphed into a comparative study of how early modern Ireland and Scotland - as examples of what I think Norberto referred to as peripheral countries - can challenge traditional understandings of how historic globalisation worked. How do they integrate into the British world system through the seventeenth to nineteenth centuries? Answering this question involves looking at the effect on finance, state formation, patterns of consumption, as well as question of how you access and consume luxuries if you're a materially poor society. What effect is there 
on your social hierarchies, your purchasing power, the traditional mediating commercial and urban agents? In the case of Scotland and indeed Ireland, these two societies immediately challenge some of the basic assumptions. For example, globalisation is not shoring up the European state; in the case of Scotland and Ireland, it obliterates them. They are subsumed into a bigger unit. So, as examples, they immediately begin to pose questions about some of the ways we calibrate and assume that Europe operates as an unproblematic 'core'. In the shape of places like Ireland and Scotland, Europe has its own peripheries.

My own specific interest is how might these relatively small, materially impoverished societies have wider significance and help us to understand early modern or proto-globalisation. We're talking pre-1815 developments here; this has led me in recent work into thinking about some of the more influential models. When you read older frameworks like Wallerstein's world-systems, Pomeranz's Great Divergence, or even Parthasarathi's super Why Europe Grew Rich and Asia Did Not, they are not well calibrated to societies like Scotland and Ireland. Perhaps understandably, they privilege what they call the core regions of Europe. That basically means Amsterdam, Lisbon, Seville, London, their hinterlands, North West France etc. The scope and ambition of these models mean they do not give us a particularly sensitive ability to understand how societies like Scotland and Ireland - noted by everyone as being both extremely poor and prone to mobility - operated. After all, these countries lacked some of the key financial state and societal infrastructures which, according to Pomeranz, gave areas like the Netherlands or England their comparative advantages over South Asia or other similarly productive parts of the world, like South East coastal China. Scotland and Ireland did not have these comparative advantages. They were impoverished by conventional measures of wealth. They were seen by contemporary observers as exemplars of poor Europe. They were deeply unequal societies, and were commented upon as such. They did not have a large urban sector. They were societies where the aristocracy and the supposedly old feudal order remained hugely powerful. They were more like Poland or Lithuania in key respects.

As supposedly peripheral countries, they relied upon modes of expansion that were necessarily different, and that led me into looking particularly at how Ireland and Scotland branched into Asia. There is a lot of work done on the Atlantic with regard both these societies. But until you understood the huge expansions into Asia you could not then say that these modes of expansion were truly global. A number of concepts really come to the fore when you look at what I am going to describe as "poor region globalisation'. Human capital emerges as the mode of expansion, not big state structures. Scottish and Irish society had very little or no venture finance, so they could not mobilise monetary capital. What they did instead was to deploy or throw people at the problem. I want to stress that this mode of expansion is not strictly diasporic as it is often understood in global history, as the sort of migratory maiden hand of the movement of capital. This 
is certainly the movement of capital: but it is configured in the form of the movement of people. It is a mode of globalisation heavily dependent on human capital. The 'poor region' answer to the problem of a lack of capital can be recovered in the ways in which Ireland and Scotland per capita were moving very large numbers of people all over the world, increasingly by 1700 and certainly by 1800 .

Their examples also reveal how incredibly sensitive and prone to diversity these economies of human capital were. This is because, within Scotland and Ireland, you ended up with sub-regions that specialised in the movement of particular types of human capital rather than others. Crudely put, Ireland relied upon a 'high volume' economy, i.e. the movement of large numbers. The problem is that Irish society found it difficult when repatriating the material or finance capital. Yet this is the whole point of a human capital economy. You send people out; you get money back. Scotland moved far less human capital, but what it did move tended to be what sociologists describe as 'high value'. These individuals were imbued with large amounts of cultural capital. The ability to generate high value human capital was partly down to early modern Scotland's large educational sector. So, as a society, Scotland was moving less people. But the results were that very high rates of capital repatriation returned.

Both Ireland and Scotland were moving people across the global, but this generates new forms of material inequality. Scotland accrued greater material advantage but Ireland did not. Countries reliant on human capital will often generate huge regional inequalities, leaving parts of a supposedly same nation to get richer, while other areas get materially poorer. The West of Ireland and the Highlands ended up in modes of human capital exportation that made them progressively poorer, while Glasgow, Bristol, Dublin, or Belfast, got materially richer. These divergences led me into the idea of glocalism; that is, understanding the big, structural forces via the local level.

I think glocalism is a hugely useful framework. It enables us to still talk about transnational networks, mediated through national frameworks of analysis, but in ways that are sensitive to diversities on the ground. I think it has got major implications for how we might renew area and regional studies. I think too that the family unit, or the idea of 'the familial state', is going to become a major way in which global history will be explored in the future. To this I should add religion. One of the biggest differences between Ireland and Scotland was ultimately that the religious cultures in both societies tended to produce human capital movements that were structured in different ways. I could see religion as being another mode that will be revisited in useful ways in the future.

Amitava Chowdhury: My theoretical interests are in the areas of global historiography and the meaning of diasporas, but empirically I have been interested in two broad areas: Indian indentured labour and the late history of slavery and fugitive slaves. Drawing from my own areas of research, I think I can talk a bit about imagining global history in a different way. The common perception within the historical academe is that the global 
is a spatial concept, a concept dealing with an expansive spatial unit, possibly the entire planet. The American anthropologist, Arjun Appadurai, had an interesting critique in mind when he said, "We cannot simplify matters by imagining that the global is to space what the modern is to time." 13 For Appadurai, modernity is not a linear chronological movement from the past to the modern, but often is "an elsewhere" for many societies. Similarly, the global as a spatial concept is inadequate and must also be read as a "temporal wave." Thus, we need to disabuse our students, universities, and larger academia from the idea that the global is solely or necessarily a macro-historical perspective. It does not have to be a spatial category that encompasses the entire planet.

Here, R. Bin Wong's China Transformed might be quite useful. ${ }^{14}$ Bin Wong, in the context of late imperial China, shows the workings of a "fractal quality" - the replication of arrangement of historical structures in multiple scales and levels of government. So, drawing from my own work on indentured labour, I see a very interesting pattern on how imperial policies on a global imperial scale are repeated and replicated in local colonial scales in various cash crop plantations in the Caribbean and the Indian Ocean. Thus, structures of inequality and poverty and hierarchies of poverty-somewhat different in each individual context - are woven together by a larger global imperial backdrop. Thus, the goal of global history is to not flatten the world and identify universal patterns, but rather to trace how larger processes are manifested differently in different local contexts. We can choose to disabuse ourselves from the spatial category of the global and rather look at it as fractals of replications of structure in smaller local scales working within a larger global imperial backdrop.

And, finally, assuming that there are graduate students in this room, I want to underline Meha's point on global history and employability. Perhaps it is an important thing to talk about, especially on an occasion where we are launching a new program in global history. I remember rather wistfully that when I started my doctoral research, the general wisdom was that you needed to specialise in a geographical area and then impose a global history approach. Otherwise you would not be employable. I think that has changed and changed rather radically. I now supervise four doctoral projects that have thrown away the regional scaffolding and the misleading frames of artificial geopolitical units. And similarly, when I look at new PhDs coming out from the leading global history programs in the US, including Harvard, I see that people have started global historical questions that are not tied to any regional (and certainly not national) specializations. If anything, at least in the last five or six years, such global projects have been more employable within the larger discipline. Therefore, just as we have to disabuse ourselves

13. Arjun Appadurai, Modernity in Large: Cultural Dimensions of Globalization (Minnesota: University of Minnesota Press, 1996), 9. Appadurai goes on to say that, "For many societies, modernity is an elsewhere, just as the global is a temporal wave that must be encountered in their present."

14. Roy Bin Wong, China transformed: historical change and the limits of European experience (Ithaca: Cornell University Press, 1997). 
from the idea that global history is merely a macro-historical perspective, we should also correct our stance vis-à-vis graduate and postgraduate training and embrace the fact that global projects are indeed employable. That is my sense, but I am, of course, open to corrections and other thoughts.

Meha Priyadarshini: Building on what Amitava just said about the utility of global history I wondered if this might be a moment to briefly mention the Jeremy Adelman article that came out in 2017 where he criticises global history and portends its demise. ${ }^{15}$

Julia McClure: Indeed, Adelman's Aeon article opened an important debate on the current state of global history and the implications of recent transformations of the political context in which global historians are writing today. We had a discussion group on it when I arrived at Glasgow last year. Jeremy Adelman was also at one of Warwick GHCC's recent conferences (April 2018) on 'scales, spaces, and contexts, in the history of the local and global,' part of the AHRC Global Microhistories network. He gave a presentation on 'Global History Now - Can we Reposition the Local?' During his presentation he was asked to expand more on his recent Aeon article. The article seemed to suggest the imminent end of global history as the dreams of living in a more cosmopolitan world have faded and we have witnessed a resurgence of ethno-nationalism and a hardening of borders. Adelman observed how the field of global history had rapidly expanded but now seemed to describe the world in a way that was 'out of step with the times'. He pointed to many methodological problems within global history, such as the limitations of language and the dominance of English in describing the world, and the fact that the production of global history did not become more globalised but was led by elite centres in the Anglo-American world. In this article Adelman claimed that 'to some extent, global history sounds like a now defunct Clinton Global Initiative, a shiny, highprofile endeavour emphasising borderless, do-good storytelling about our cosmopolitan commonness'. It sounds quite damning, but Adelman responded that the article has been mis-read and was not proclaiming the end of global history, only that global historians needed to change what they were doing, to incorporate non-elite histories, and remember the power of place, which has remained important - especially to poorer people.

Meha Priyadarshini: While his criticisms might be valid to some extent, scholars have made such arguments before and the field has responded. I can think of many works that avoid exactly the pitfalls that you have described. I am thinking of the global histories of cotton, or the works on merchant networks that are both global and intensely local, i.e. the works of Engseng Ho, Sebouh Aslanian, and Francesca Trivellato, and works that look at the impact of international orders precisely on the poor and disenfranchised, such 
as those by Adam McKeown and Matt Connelly. Adelman was criticized for his short sightedness and perhaps, rightly so. ${ }^{16}$

Julia McClure: There has been a lot of response. Indeed Richard Drayton and David Motadel wrote an article published in the Journal of Global History in 2018 opening a discussion on the futures of global history in response to Adelman's Aeon piece, and rebuffing its criticisms of global history. Adelman has responded and claimed that the reaction to his article mis-represented his argument, and that he still thinks global history has a future.

This round table can be seen as part of the discussion that has been opened on the future of global history, and there seems to be some consensus that global history needs to transcend its elite focus. Poverty and inequality need to be central to the future of global history. This raises new conceptual possibilities for the ways we think about space and movement, the immobilities as well as the mobilities, resistance and friction as well as flow. We also need to think about how global history is written, by whom and for whom, and to think about the ways global history as a discipline can be represented as it moves forward.

Meha Priyadarshini: I actually have to thank Julia because I hadn't thought about my work as addressing questions of inequality, but maybe there are a few ways in which it does. As I mentioned before, I work on the connections between colonial Latin America and Asia and for my book I focused on Asian commodities traded to the Spanish American colonies. The project was a multi-sited work, and so it considers the same trade network from several different vantage points, and in so doing, highlights several different inequalities.

One inequality is a historiographical one. When we think about the early modern period and consumption of Asian commodities, the images that probably most often come to mind are portraits of elite European families drinking tea in porcelain cups in their parlour rooms. We are aware of the impact that trade with Asia had in western Europe. In my work I point out that societies in Spanish colonies also had access to these goods, and within those societies, indigenous people too could wear fine silks or commission folding screens made after Japanese models. It upends our idea of who had access to luxuries in the early modern period and challenges the centrality of Europe in

16. Giorgio Riello, Cotton: The Fabric that Made the World (Cambridge: Cambridge University Press, 2013); Sven Beckert, Empire of Cotton: A Global History (New York: Alfred A. Knopf, 2015); Engseng Ho, The Graves of Tarim: Genealogy and Mobility across the Indian Ocean (Berkeley: University of California Press, 2010); Sebouh Aslanian, From the Indian Ocean to the Mediterranean: The Global Trade Networks of Armenian Merchants from New Julfa (Berkeley: University of California Press, 2014); Francesca Trivellato, The Familiarity of Strangers: The Sephardic Diaspora, Livorno and CrossCultural Trade in the Early Modern Period (New Haven: Yale University Press, 2012); Adam McKeown, Melancholy Order: Asian Migration and the Globalization of Borders (New York: Columbia University Press, 2011); Matthew Connelly, Fatal Misconception: The Struggle to Control World Population (Cambridge, Mass: Harvard University Press, 2010). 
early modern global connections. I argue that in colonial Latin America it was not just an aspiration to be cosmopolitan that drove the desire to consume Asian goods, but the direct trade with Asia also allowed the colony to distance itself from the metropole. So, when I situate myself in colonial Latin America, the transpacific connection to Asia is hugely important

However, if you look at the same trade from the Asian perspective, while we can see that it definitely benefited many Chinese and other merchants, the arrival of the Spanish in the Philippines also disconnected many communities from pre-existing trade networks and took away their livelihoods. And even in China, it is not clear that the producers of the commodities that were so important to global trade really benefited from this increasingly connected world. Their own experience of producing silk or porcelain was very different from that of the people who were using these goods around the world.

So one thing that we really need to keep in mind as we think about inequality is about the nature of global connections, and this is especially true for early modernists because we become really excited about all the connections that exist in this period because they were new. However, the creation of a new connection often meant the severing of an older one, and we should always be aware of this.

Julia McClure: Thanks for this. Another of the key debates in global history has concerned the question of why Latin America has been left out of global history. This issue was raised in an article published by Matthew Brown in the Journal of Global History in 2015. I contributed to a panel on this question at the Society of Latin American Studies Annual Conference in 2016. Brown argues that Latin Americanists have feared that global history would contribute to the loss of culture-specific knowledge of Latin America, which has contributed to Latin Americanists and global historians remaining separate. This is a question of methodology as well as perspective. Brown noted that 'global history has been slow to see Latin America as one of its centres of gravity, which instead were believed in Eurasia. For Meha and I, who are global historians of the early modern Spanish Empire, this seems at once strange and familiar. On the one hand, it seems clear that especially in the early modern period, Latin America was central to global connections. On the other hand, it is true that the history of Latin America is often underrepresented within global history centres and that it can be difficult to involve people in Latin American centres in global history projects. This raises methodological questions for the field of global history, since regional centres are essential for the development of skills and expertise in languages and cultures. But it is also important to think about the questions that global history is asking for it to be of interest to Latin Americanists and for Latin American history to be incorporated in a meaningful way, which may also mean challenging some of the normative assumptions within global history.

Sarah Easterby-Smith: I would like to echo much of what has already been said, especially Meha's contribution above. I would like to take up the points about scales and 
especially the relationship between the micro and the global.

As Amitava intimated above, one of the criticisms that global or world history has received is based on a concern that it tries to do the impossible - to connect up everything all at once or cover a massive scale. In general, the 'global' histories of science produced in the past few decades have been less subject to such criticism. This is because they tend to take a more 'microhistorical' approach, focusing on the movement of specific items, ideas, or individuals, and then relating the evidence upwards to bigger concepts or social formulations.

Recent history of science has been less receptive to the large-scale variety of global or world history partly due to developments within the field over the second half of the twentieth century. Mid-twentieth-century scholars like George Basalla, Joseph Needham and their students wrote about the purported 'spread of Western science' outwards from Europe and examined the extent to which non-European cultures 'contributed' to 'modern' (i.e. Western) science ${ }^{17}$ But that broad-brush, Eurocentric approach to thinking about the history of knowledge has changed radically; most history of science now seeks to locate subjects within their contemporary cultural and social contexts. This work forms part of a broader move that emphasised the value of looking at interactions and connections and which thus found grand narratives of scientific 'progress', or global 'divergence', unsatisfactory. Historians of science increasingly sought to understand practice and to focus on the contexts of knowledge making, knowledge exchange and knowledge creation. This has been very important and very helpful for thinking about global histories (plural) of science.

Historians of science have also paid attention to the issues that global history raises about methodology, sources, and Eurocentrism. Indeed, some - not least Sujit Sivasundaram, Kapil Raj, and Lissa Roberts - have argued persuasively that we should revise the ways in which we collect and interpret evidence. As the majority of sources available have been compiled and archived by Europeans, they and others have suggested methods for reading the evidence so as to revise the categories that we apply in our research, moving away from dichotomous modes of thought and aiming, in Sivasundaram's words, to 'fragment' our own knowledge traditions. ${ }^{18}$ Raj has reassessed the way in which we understand the 'circulation' of information in the context of postcolonial scholarship, emphasising agency (even in a context of inequality) and the transformations that can take place on all sides. ${ }^{19}$ Roberts has proposed that the concept of 'dispersion' might offer us greater analytic potential because it allows us to start our analyses within 'centres of accumulation' (rather than in Western institutions), and avoids the closure that 'circulation'

17.George Basalla, “The Spread of Western Science," Science, 156 (1967), 611-622; Joseph Needham, Science and Civilisation in China, 7 vols. (Cambridge: Cambridge University Press, 1954-2005).

18. Sujit Sivasundaram, "Sciences and the Global. On Methods, Questions, and Theory," Isis, 101 (2010), $146-158$.

19. Kapil Raj, "Beyond Postcolonialism ... and Postpositivism: Circulation and the Global History of Science," Isis, 104, 2 (2013): 337-347. 
can imply. ${ }^{20}$ All emphasise the value of developing micro-historical approaches that pay close attention to local circumstances, specificities and perspectives, and then relating the evidence upwards and outwards to larger-scale processes. This is certainly what I am trying to achieve in my current project about the circulation of knowledge in the Indian Ocean World. But I think there's still a lot more work to be done and a lot more scope for creativity in terms of rethinking how we go about our research - it's an exciting area.

I would also like to say something - and this is more directly in response to Amitava's comments, above - about the state. Over the past few decades, early modern global historians, as well as historians of science, have paid increasing attention to the historical roles played by things, objects, people, go-betweens and networks. ${ }^{21}$ This is fantastic and has led to some very helpful contributions to the historiography, but that should not be at the expense of thinking about bigger frameworks such as the state or bigger structures, such as the major trading companies. We need to retain those within our frames of analysis as well, and to aim to understand the ways in which the big structure relates down to the individuals and how that relationship was then nuanced within local situations and local places - very much along the lines that Andrew sketched out above. In some ways, this approach will bring us back to questions that were posed in the 1990s, but I hope that, as we develop a new set of global history methodologies, we will be able to ask and hopefully answer these in different ways.

Julia McClure: Thank you very much, and I think this recurring point about inequalities of knowledge is very important. It draws our attention to the epistemologies, and also to normative structures such as law, which have helped to structure and perpetuate inequalities.

Sarah Easterby-Smith: Absolutely. Some of those points precisely have been taken up in a recent special issue of Itinerario about legal cultures in the Indian Ocean World. ${ }^{22}$

Jelmer Vos: How has the field developed? I can reflect a little on that question regarding Africa. As Omar Gueye has recently pointed out, there is growing recognition of Africa's legitimate place in the study of global history. Africa's centrality to global history has been most effectively underlined by studies of the Atlantic slave trade. Historians like Joseph Inikori stress the point that African slave labour was fundamental to the creation of an integrated world economy centred on the Atlantic basin. ${ }^{23}$ More generally, in the

20. Lissa Roberts, “Le centre de toutes choses': Constructing and Managing centralization on the Isle de France," History of Science, 52, 3, (2014), 319-342.

21. Simon Schaffer, Lissa Roberts, Kapil Raj and James Delbourgo (eds.), The Brokered World. Go-Betweens and Global Inteligence, 1770-1820 (Sagamore Beach: Science History Publications, 2009).

22. Mahmood Kooria and Sanne Ravensbergen (eds.), "The Indian Ocean of Law: Hybridity and Space," Itinerario, 42 (Special Issue 2) (August 2018).

23. Joseph E. Inikori, "Africa and the Globalization Process: Western Africa, 1450-1850," Journal of Global History 2, 1 
wake of John Thornton's foundational study, Africa and Africans in the Making of the Atlantic World, several historians have proposed different ways in which the agency of Africans was fundamental to the development of trade relations with Europe and the creation of transatlantic connections. ${ }^{24}$ And we now see increasingly sophisticated ways of analysing African contributions to the Atlantic world. James Sweet, for instance, has used Portuguese Inquisition records to make a case for an Atlantic world created on African terms. He claims that Africans were not merely influencing the religious structures put in place by European empires, but imposed their own religious traditions on them, creating an "alternate modernity." 25

More generally, Africanist historians working on different parts of the continent are showing important regional contributions to Africa's integration into global religious and economic networks. Africa is no longer seen as a passive periphery of this or that world system. Instead, the way forward is to see Africa as containing multiple hubs in the creation of global networks. Places like Jenne, Anomabo, or Zanzibar were not just sitting on the margins of other people's empires but were central nodes in the global webs they got tied into and which they subsequently helped shape. ${ }^{26}$ This does not mean that Africans were suddenly controlling the system, but by understanding Africa's contributions we can at least reframe the question about what it means to be at the periphery of a world system centred in Asia or Europe. ${ }^{27}$

In relation to the question about global inequalities, the idea that Africans entered the world economy on unequal terms, as Rodney, Wallerstein and others used to argue, has become debatable. Africans entered as equal partners and while their societies might not have gained the same benefits from their integration in the global economy - think of economic development - it did not necessarily leave them poorer either. And that, in turn, was related to what some argue was the continent's poor integration in the world economy: perhaps not so many Africans were affected by global economic developments. So, here we might reach the limits of global history!

In fact, Africanist historians have been some of the fiercest critics of global history, or at least the kind of histories that privileges Africa's connections with external worlds, as if everything emanates from these linkages, which some argue had only limited reach. Not everything that happened in the African past was determined by maritime

(2007), 63-86.

24. John K. Thornton, Africa and Africans in the Making of the Atlantic World, 1400-1800, Second Edition (Cambridge: Cambridge University Press, 1998).

25. James H. Sweet, Domingos Álvares, African Healing, and the Intellectual History of the Atlantic World (Chapel Hill: University of North Carolina Press, 2011).

26. Randy J. Sparks, Where the Negroes are Masters: An African Port in the Era of the Slave Trade (Cambridge, MA: Harvard University Press, 2014).

27. Michael N. Pearson, Port Cities and Intruders: The Swahili Coast, India, and Portugal in the Early Modern Era (Baltimore: John Hopkins University Press, 1998); Jeremy Prestholdt, Domesticating the World: African Consumerism and the Genealogies of Globalization (Berkeley: University of California Press, 2008). 
connections with people and places located outside the continent. ${ }^{28}$ Global history does indeed seem to privilege maritime connections between continents. You might wonder, could global history also be intra-continental? Anyway, the two positions are not mutually exclusive. You can study African contributions to global developments while at the same time recognising that not all of Africa is equally, or at every level, affected by such developments.

Other fascinating developments in the field come from environmental history, with scholars exploring botanical exchanges (initially in the Atlantic, but others have begun to look at the Indian Ocean) or the spread of malaria out of Africa to other parts of the world. ${ }^{29}$ Interestingly, these histories are often tied to histories of human migration, so interdisciplinarity is becoming increasingly important. And, to come back to the earlier point on the significance of maritime connections, we should note that crops introduced in Africa via maritime routes, like maize, cassava and the banana, often did travel very far and fundamentally transformed the lives of people deep inland. ${ }^{30}$

Finally, there are interesting developments in Africa related to the history of global commodity chains. Africa has, of course, a long history of exporting products other than slaves. Some of these commodities, like gold, ivory, rubber, as well as some agricultural crops, played significant roles in the global economy, but the study of their production and trade has often been through a predominantly Africanist lens, focussing on the African response to external demand for this or that raw material. Bringing in a global perspective means looking at ways in which Africans shaped foreign markets, not just as producers but also as consumers of goods made in other parts of the world.

Julia McClure: This is an important reflection on how global history is transforming African history and vice versa. I think the question of whether global history could also be intra-continental raises signposts for a future direction in global history and the history of Africa. Global history has often focused upon maritime connections. In 2010 Maria Fusaro and Amelia Polania published an edited volume demonstrating the importance of maritime history to global history. It observed that the sea has been an important conduit for the development of global connections and that global trade and globalisation emerged with the Manila galleon trade and the opening of trans-Pacific sea routes. ${ }^{31}$ Yet this focus on maritime connections has often prioritised certain places and peoples, often meaning that global history has been written not only as the history of

28. Pier Larson, "African Slave Trades in Global Perspective," in The Oxford Handbook of Modern African History, eds. John Parker and Richard Reid (Oxford: Oxford University Press, 2013), 56-76.

29. James L. A. Webb Jr., Humanity's Burden: A Global History of Malaria (Cambridge: Cambridge University Press, 2009). 30. Judith A. Carney and Richard Nicholas Rosomoff, In the Shadow of Slavery: Africa's Botanical Legacy in the Atlantic World (Berkeley: University of California Press, 2009); James C. McCann, Maize and Grace: Africa's Encounter with a New World Crop, 1500-2000 (Cambridge, MA: Harvard University Press, 2005); David Lee Schoenbrun, A Green Place, a Good Place: Agrarian Change, Gender, and Social Identity in the Great Lakes Region to the 15th Century (Portsmouth, NH: Heinemann, 1998).

31. Maria Fusaro and Amelia Polania, Maritime History as Global History (Liverpool: Liverpool University Press, 2010). 
maritime connections but as the history of European empires. Reorienting perspective to an intra-continental perspective might facilitate the decolonisation of global history as it transforms the coordinates of 'centre-periphery' established by world-systems analysis. However, in doing so it should not undo the gains made by global history in overcoming the boundaries imposed by area studies. The trans-continental approaches to Eurasia may offer some examples. Scholarship that has taken Eurasia as its unit of analysis has transformed understandings of both Europe and Asia, and questioned the economic and cultural boundaries between the two. ${ }^{32}$ Histories of the silk roads have reoriented our understanding of geopolitical, cultural, and economic landscapes, and shown that places like Samarkand were not peripheral but centres of economic and cultural exchange. ${ }^{33}$ Crucially, this Eurasian approach has also changed how we think about Europe and European uniqueness. ${ }^{34}$ These projects are in a sense correcting some of the geopolitical inequalities of older historical imaginaries.

Steven Serels: I want to pushback against the choice to focus on inequality instead of poverty. Poverty is different from inequality. Inequality is a relative state and poverty is an absolute state. There can be inequality of wealth distribution between two rich people if one is richer than the other. This doesn't change the fact that they are both rich. Unfortunately, the focus on inequality does not address the fact that there is abject poverty in the world. It also doesn't critique the dominant narrative in the field of global history, which is the accumulation of wealth. The focus on, for example, the disparity between the relative rise of Europe vis-à-vis China in the nineteenth century does not address the history of poor people themselves.

I also want to push against any kind of knee-jerk veneration or critique of global processes. Over the past two years, I have witnessed a radical shift in the way globalization has been criticized. It used to be that globalization was critically identified as a harm that was replacing culture in the developed world with brands and was producing economic harm and ecological devastation in the developing world. Now, the critical voices are for deeper global interconnections and against structures that divide the world into hermeneutic localities. I think now especially we need to be nuanced in our assessment of globalization and global networks. We need to see them as a kind of resource that comes with its own dangers. This I think gets at a new way of honestly doing global history from below. It is unmistakable that for much of the Global South, modern globalization has been linked to the spread of poverty. Current conditions have made it impossible for people to live in the rural countryside. The real question that needs to be asked is: what

32. Subrahmanyam, Sanjay. "Connected Histories: Notes towards a Reconfiguration of Early Modern Eurasia", Modern Asian Studies, 31, 3 (1997), 735-762; Victor Lieberman, Strange Parallels, Southeast Asia in Global Contex, c. 800 - 1830, vols 1 and 2 (Cambridge: Cambridge University Press, 2003 and 2010).

33. Peter Frankopan, The Silk Roads, A New History of the World (London: Bloomsbury, 2015).

34. Charles West ed. "Religious exemption in Pre-Modern Eurasia, c. 300 - 1300 CE," Medieval Worlds, 6 (2017). 
kept people in the countryside before the mid-twentieth century? We need to recognize that people stayed on their land not because they lived in hermeneutic localities, cut off from the globalizing world. Rather, they lived in an already global world. Until relatively recently, distant connections were a resource that helped produce local rootedness. We need to understand why that was true then and no longer true now.

Julia McClure: I think our focus on poverty in the work that we are doing through the poverty research network and in our own studies will be an important contribution to the field of global history as it undergoes 'the inequality turn'. As global inequality continues to increase, global historians have an increasing obligation to explain the making of our unequal world, and understanding the dynamics of poverty will be an important part of this project. Global history's 'poverty turn' will also be a call to radicalise our methodologies within global history, to incorporate social history, and to produce global history from the bottom up. It will also require sharper analysis of power, from economic, legal, cultural, and political perspectives to understand how pathways towards inequality have been legitimated and how poverty has been normalised and weaponised. Focusing on poverty, within the framework of inequality, also offers opportunities to understand the history of resistance. The strategies that have been successful as well as those that have failed.

Norberto Ferreras: Mostly, when we think about global history we are thinking about the history of capitalism, and when I say periphery - I use the term ironically, of course, because there are not 'cores' and 'peripheries': each part depends on the other, and from this point of view are interdependent. Brazil during the nineteenth century, was the core of a network of slavery, merchandise, and capital. Identifying this core region as a periphery indicates the historic inequalities that have been engendered by the history of capitalism. The basis of capitalism is to create inequalities. For example, on chapter twenty-five of Das Capital, Marx analysed colonisation relationships, and he presents a beautiful example of the difficulties of translating capitalism to peripheries or to the colonies. This is the case of Mr Peel, an entrepreneur, who tried to colonize New Holland (Perth in Western Australia). He brought everything to Swan River (downtown Perth). He brought machines, seeds, and workers, but it was impossible to translate the relations of production. The Swan River region had plenty of land, and Mr. Peel's workers preferred to live on their own, leaving their master. The Swan River had plenty of land and workers preferred to carry on their own production. Without workers there isn't capitalism. As Brazil needed to become capitalist, therefore it needed to separate workers from land and their means of production. And this took a great effort, which continues today. Inequality is the base of Capital, and so we need to put inequality as one of the most important categories to be analysed. Furthermore, globalisation and the history of capitalism are entangled. From Polanyi to Pomeranz, and from Sanjay Subrahmanyan to Osterhammel, global historians have been studying 
the history of capitalism, but they didn't pay enough attention to inequality as the key issue of capitalism. I didn't see yet one book about globalisation outside of capitalism.

Julia McClure: Thank you Norberto for these insights which raise questions about the way global history has often been written about the history of capitalism. It is very interesting to think about the question of globalisation from outside capitalism. I have often thought about this in relation to the history of the Franciscan Order, which became, arguably, the first global religious order, and emerged as a resistance movement against the spread of money and markets. They often travelled with merchants, following world trade routes, but they continued to question the relationship between economic values and spiritual values and to criticise cultures of accumulation. For me, following the history of the Franciscan Order has been a small opening to think about alternative narratives of global history, and this in fact led me to my current research on the role of poverty in the making of the modern world. This panel has been a great opportunity to think about the different directions that global histories of poverty and inequality can take us.

I want to finish by thanking all participants for their contributions, which have indicated the different ways that discussions on inequality can lead future directions in global history. These inequalities are not only economic, but also political, legal, and epistemological. Thinking about inequality helps us as global historians to resist trends towards the homogenisation or universalisation of certain epistemological categories and world views. Our aims as global historians must be to capture the lost visions of the world and value systems that are being erased by the continued spread of capitalism and neoliberalism that are penetrating all institutions, including the institutional sites of knowledge production. As we live in an unequal world our role as global historians is to explain how we arrived here, and the alternative ways of living, social relations, and relations with the environment, that have been lost along the way. 


\section{Bibliography}

Adelman, J. 'What is Global History Now?' Aeon, 2 (2017).

Andrad, Oswald de. "Manifesto of Pau-Brasil Poetry." Trans. Stella M. de S. Rego. IN: "Latin American Literary Review XIV: 27" (January-June, 1986)

Appadurai, Arjun. Modernity in Large: Cultural Dimensions of Globalization . Minnesota: University of Minnesota Press, 1996).

Aslanian, Sebouh. From the Indian Ocean to the Mediterranean: The Global Trade Networks of Armenian Merchants from New Julfa. Berkeley: University of California Press, 2014.

Basalla, George. “The Spread of Western Science.” Science, 156 (1967): 611-22.

Beckert, Sven. Empire of Cotton: A Global History. New York: Alfred A. Knopf, 2015.

Bertrand R. L'Histoire à parts égales. Récits d'une rencontre, Orient-Occident (XVIeXVIIe siècle). Paris : Seuil, 2011.

Bin Wong, Roy. China Transformed: Historical Change and the Limits of European Experience. Ithaca: Cornell University Press, 1997.

Brown, M. "The Global History of Latin America", Journal of Global History, 10, 3 (2015): 365-386.

Connelly, M. Fatal Misconception: The Struggle to Control World Population. Cambridge, Mass: Harvard University Press, 2010.

Drayton R., and Motadel D., "Discussion: the futures of global history." Journal of Global History, 13, 1 (2018): 1-21.

Frankopan, P. The Silk Roads, A New History of the World, London: Bloomsbury, 2015.

Fusaro, M., Polania, A., Maritime History as Global History. Liverpool: Liverpool University Press, 2010.

Gueye, Omar. Mai 1968 au Sénégal : Senghor face aux étudiants et au mouvement synodical. Paris: Éditions Karthala, 2017. 
Guha, R. History at the Limit of World-History. New York: Columbia University Press, 2003.

Hardt, Michael and Negri, Antonio. Empire. Cambridge, Massachusetts, Harvard University Press, 2000.

Ho, Engseng. The Graves of Tarim: Genealogy and Mobility across the Indian Ocean. Berkeley: University of California Press, 2010.

Inikori, Joseph E. "Africa and the Globalization Process: Western Africa, 1450-1850." Journal of Global History, 2, 1 (2007), 63-86.

Kooria, Mahmood and Sanne Ravensbergen, eds. "The Indian Ocean of Law: Hybridity and Space.” Itinerario, 42. Special Issue 2 (2018).

Larson, Pier. "African Slave Trades in Global Perspective," in The Oxford Handbook of Modern African History, eds. John Parker and Richard Reid. Oxford: Oxford University Press, 2013.

Lieberman, V. Strange Parallels, Southeast Asia in Global Context, c. 800 - 1830, vols 1 and 2. Cambridge: Cambridge University Press, 2003 and 2010.

Mazlish, M. "Comparing Global History to World History." The Journal of Interdisciplinary History 28, 3 (1998): 385-395.

Marnie Hughes-Warrington, ed. Palgrave Advances in World Histories. Basingstoke: Palgrave Macmillan, 2004.

Marx, Karl. Capital: A Critique of Political Economy, Vol. 1. London: Penguin, 1990.

McClure, J. The Franciscan Invention of the New World. Basingstoke: Palgrave Macmillan, 2016.

McKeown A. Melancholy Order: Asian Migration and the Globalization of Borders. New York: Columbia University Press, 2011.

Needham, Joseph. Science and Civilisation in China, 7 vols. Cambridge: Cambridge University Press, 1954-2005. 
Niane, Djibril Tamsir. Soundjata ou l'Épopée Mandingue. Paris: Présence Africaine 1960. English Translation: Sundiata: an epic of old Mali. London: Longmans, 1965.

Osterhammel, J. The Transformation of the World: A Global History of the Nineteenth Century. Princeton, Princeton University Press, 2014.

Parthasarathi, Prasannan. Why Europe Grew Rich and Asia Did Not. Cambridge: Cambridge University Press, 2011.

Pearson, Michael N. Port Cities and Intruders: The Swahili Coast, India, and Portugal in the Early Modern Era. Baltimore: John Hopkins University Press, 1998.

Yves Person, Samori: une revolution dyula. Dakar: I.F.A.N., 1968.

Piketty, T. Capital in the Twenty First Century. Harvard: Harvard University Press, 2014.

Polanyi K. The Great Transformation. Second edition. Boston: Beacon Press, 2002.

Pomeranz, P. The Great Divergence: China, Europe, and the Making of the Modern World Economy. Princeton, Princeton University Press, 2000.

Prestholdt, J. Domesticating the World: African Consumerism and the Genealogies of Globalization. Berkeley: University of California Press, 2008.

Raj, Kapil. "Beyond Postcolonialism ... and Postpositivism: Circulation and the Global History of Science." Isis, 104 (2013): 337-47.

Ranajot Guha's History at the Limit of World-History. New York: Columbia University Press, 2003.

Riello, Giorgio. Cotton: The Fabric that Made the World. Cambridge: Cambridge University Press, 2013.

Roberts, Lissa. "'Le centre de toutes choses': Constructing and Managing centralization on the Isle de France." History of Science, 52 (2014): 319-42.

Schaffer, Simon, Roberts, Lissa, Raj, Kapil, and Delbourgo, James, eds. The Brokered World. Go-Betweens and Global Inteligence, 1770-1820. Sagamore Beach: Science History Publications, 2009. 
Sivasundaram, Sujit. "Sciences and the Global. On Methods, Questions, and Theory." Isis, 101 (2010): 146-58.

Sparks, Randy J. Where the Negroes are Masters: An African Port in the Era of the Slave Trade (Cambridge, MA: Harvard University Press, 2014).

Subrahmanyam, Sanjay. "Connected Histories: Notes towards a Reconfiguration of Early Modern Eurasia.” Modern Asian Studies, 31, 3 (1997), 735-762.

Sweet, James H. Domingos Álvares, African Healing, and the Intellectual History of the Atlantic World. Chapel Hill: University of North Carolina Press, 2011.

Thornton, John K. Africa and Africans in the Making of the Atlantic World, 1400-1800, Second Edition. Cambridge: Cambridge University Press, 1998.

Trivellato, Francesca. The Familiarity of Strangers: The Sephardic Diaspora, Livorno and Cross-Cultural Trade in the Early Modern Period. New Haven: Yale University Press, 2012.

Wallerstein, Immanuel. The Modern World System. 4 vols. Berkeley: University of California Press, 2010.

Webb Jr., James L. A Humanity's Burden: A Global History of Malaria. Cambridge: Cambridge University Press, 2009.

West, C. "Religious Exemption in Pre-Modern Eurasia, c. 300 - 1300 CE." Medieval Worlds, 6 (2017). 